\title{
Socrative in Teaching Tenses: Indonesian Students and Lecturers' Perceptions
}

\author{
Maslawati Mohamad', Dafita Dwi Lestari ${ }^{1}$, Azizah Mohd Zahidi ${ }^{2}$, Mohd Effendi Mohd Matore ${ }^{1}$ \\ ${ }^{1}$ Faculty of Education, National University of Malaysia, Bangi, Selangor, Malaysia \\ ${ }^{2}$ PERMATApintar National Gifted Centre, National University of Malaysia, Bangi, Selangor, Malaysia \\ Email: maslawati@ukm.edu.my
}

How to cite this paper: Mohamad, M., Lestari, D. D., Zahidi, A. M., \& Matore, M. E. M. (2019). Socrative in Teaching Tenses: Indonesian Students and Lecturers' Perceptions. Creative Education, 10, 140-150. https://doi.org/10.4236/ce.2019.101010

Received: October 29, 2018

Accepted: January 18, 2019

Published: January 22, 2019

Copyright (c) 2019 by author(s) and Scientific Research Publishing Inc. This work is licensed under the Creative Commons Attribution International License (CC BY 4.0).

http://creativecommons.org/licenses/by/4.0/

(c) (i) Open Access

\begin{abstract}
Mastering a language not only involves four language skills-listening, speaking, reading, and writing-but also mastering the grammar and vocabulary of the language. This research was intended to investigate the perceptions of Indonesian undergraduates and their lecturers at the Islamic University of Riau toward the use of Socrative in grammar class specifically tenses. This study employed a quantitative research design. The respondents were 34 sixth-semester undergraduates who were randomly chosen and two grammar lecturers at the English Department of Islamic University of Riau in the academic year 2016/2017. The questionnaire was adapted from the technology acceptance model (TAM) by Davis, which consists of two specific variables: Perceived usefulness and perceived ease of use. Before the questionnaire was employed in this study, a pilot study was carried out to ensure the validity and reliability of the instrument. The findings of the research show the majority of respondents have positive perceptions toward Socrative. The students and lecturers provide positive responses with regard to "perceived usefulness and ease of use" of Socrative in grammar class. It is hoped that this tool not only could be used in grammar class but also in all aspects of English language learning. It is also expected that this research could assist Indonesian educators to teach more creatively.
\end{abstract}

\section{Keywords}

Socrative, Tenses, Perception, Usefulness, Ease of Use, Technology

Acceptance Model (TAM)

\section{Introduction}

English is an international language; thus, it is important for many people to be 
able to use it globally. Due to its global significance, the English language has been recognized as the most important foreign language in Indonesia since 1980s. It has witnessed tremendous growth since early 1990s, as highlighted by Alwasilah (1997, cited in Mappiasse \& Sihes, 2014). Generally, when students study English, they have to learn and master four language skills, i.e., listening, speaking, reading, and writing. Besides those four language skills, grammar and vocabulary are also important for language learning. However, grammar classes are often perceived as complicated by students (Paris \& Yussof, 2012). Therefore, it is important for educators to employ the right approach to reduce fear in learning grammar especially tenses. It will benefit the students to be highly proficient in the target language if they are able to apply knowledge on grammar in their reading, speaking, and writing. There are various strategies that could be employed by educators to improve their teaching of grammar. One of the strategies involves the integration of information and communication technology (ICT) especially in a twenty-first-century classroom.

Barnawi (2009), Dashtestani (2012), and Bolandifar (2013) stated that ICT is a beneficial tool to be used in English teaching, particularly in English as a foreign language (EFL) context. Nevertheless, the integration of ICT at schools in Indonesia particularly in English language teaching is still very low (Al-Munawwarah, 2014). However, according to Yuhetty (2002), the Indonesian government has used ICT to expand some educational opportunities. The purpose is to improve the quality of education. She also stated the use of ICT in the education domain in Indonesia includes e-learning, online courses, online tutorials, collaborative research, electronic libraries, and computer-assisted instruction (CAI).

Many researchers have reported that the integration of ICT in teaching and learning are able to amplify students' performance and teachers' productivity and efficiency (Jamil \& Shah, 2011). As stated by Sudiran (2015), in Indonesia, many students perceive that educational institutions that integrate ICT in teaching and learning as reputable institutions. It means that students have positive perception toward the application of Internet usage in school or college. Most of them believe that the success of graduates depends on their ability to apply ICT knowledge in their workplace. This is also to ascertain employability competitiveness among graduates.

In studying students' perception on the use of ICT, the technology acceptance model (TAM) is one of the most reported models as shown in Figure 1. TAM is relevant to this study because the acceptance of a technology depends on the: 1) perceived usefulness and 2) perceived ease-of-use by the users. Both of them are also the determinants of user behavior. It means that students' behavior is shaped by their perception.

Davis (1989) highlighted that users tend to use an application if they perceive it will help them to perform a job better. This variable is known as perceived usefulness. However, the perception of usefulness is also influenced by perceived ease of use. In this study, perceived usefulness and perceived ease of use of TAM 


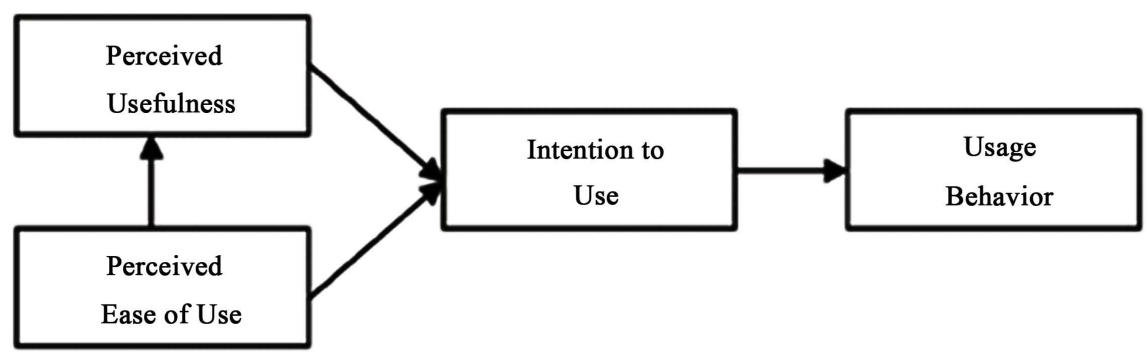

Figure 1. The technology acceptance model (Davis, 1989).

proposed by Davis (1989) were used to analyze students' perceptions toward the integration of Socrative in language learning especially tenses.

Socrative (www.socrative.com) is one of the most popular student online response systems that empowers educators to engage their students in classroom activities. Socrative provides a platform for educators to generate quiz questions, see the students' achievements or scores, and monitor their students' responses and progress in real time. It can be used anywhere and anytime. It facilitates learning and enables teachers to gain feedback to improve their teaching. Kaya and Balta (2016) stated that Socrative is an appropriate tool, which educators can integrate into their English classes to achieve better teaching and learning outcomes. O'Keeffe (2012) highlighted some benefits of using a student response system. According to him, it provides a platform for educators to generate quiz questions, see the students' scores, and monitor students' responses and progress. It enables students to cognitively process questions posed by the teacher (Awedh et al., 2014). It allows students to provide feedback and responses to questions and quizzes as language activities during a lecture (Dervan, 2014). When the feedback is immediate, educators and students could identify areas of difficulties. It also encourages students' active participation thus empowering teachers to be more engaged with their students.

Due to the benefits that Socrative could bring to the students, the researchers, who are also educators, had employed Socrative in grammar teaching. The main purpose of this study was to investigate the effectiveness of Socrative in teaching grammar. The research objectives are as follows:

1) To investigate students' perceptions on Socrative use in tenses.

2) To identify lecturers' perceptions on Socrative use in teaching tenses.

\section{Methodology}

The population was the sixth-semester students of English Study Program in the Islamic University of Riau of academic year 2016/2017. Thirty-four students of Class B were chosen as a sample by using the lottery or random selection for all classes. There are 11 males and 23 females in Class B. Their age range is between 20-23 years old. The students in Class B are of intermediate English proficiency. English for these Indonesian students are English as a Foreign language whereby English is normally used inside the classroom context only. Only this class (Class B) out of four classes of English study programme was given by the faculty dean 
to conduct this study. The researchers designed a few grammar lessons on tenses using Socrative. Other classes use traditional approach in their lessons. This class was taught by two English lecturers. Then, two lecturers who teach the course were purposively selected as the sample to answer the questionnaire on Socrative usage in grammar class particularly on tenses.

The questionnaire was adapted from the TAM by Davis (1989), which consists of two specific variables: 1) perceived usefulness and 2) perceived ease of use. The questionnaire consists of 26 items, which are divided into four parts. Part 1 consists of three questions on respondents' demographic profile. Part 2 consists of 10 questions on perceived usefulness. Part 3 consists of 10 questions on perceived ease of use. For Part 2 and 3, the items need to be answered using five-point Likert scales (strongly agree, agree, neutral, disagree, and strongly disagree). Then, for the remaining items, the respondents were asked to answer two open-ended questions in order to obtain more detailed information on the features, which are favorable or unfavorable, offered by Socrative from the students' perceptions. For item 26, which is a closed-ended question, the students were asked if they would continue using Socrative in the future. Before the questionnaire was employed in this study, a pilot study was carried out to ensure the validity and the reliability of the instrument.

The researchers guided the lecturers to use Socrative in their teaching. One of the researchers conducted six tutorials on tenses along with the lecturers. After the lecturers taught tenses in the class, the students were instructed to use Socrative to reinforce and evaluate their understanding of the lessons learnt. For each tutorial, the researcher gave handouts on tenses (simple past tense, simple present tense, past continuous tense, simple future tense, and past perfect tense). After distributing each handout, the students answered a Socrative quiz that consists of 20 multiple choice questions on the taught lesson. In the last tutorial, the researchers asked all the students to complete the questionnaire. The researchers also gave the questionnaire to the two lecturers as to obtain their perceptions on the effectiveness of Socrative in the teaching and learning tenses. There are two open-ended questions (positive and negative perception) for the lecturers to express their perception on the integration of Socrative in the teaching of tenses. The quantitative data were analyzed by using SPSS version 20 to identify the students and lecturers' responses on the use of Socrative in teaching tenses. The quantitative data are presented in percentage and frequency form.

\section{Findings and Discussions}

In general, the respondents' perceptions toward the use of Socrative in learning tenses were varied. The researchers have categorized the data into two main themes: students' perceptions and lecturers' perceptions (refer to Table 1).

\subsection{Students' Perceptions towards Socrative}

The findings show that the vast majority of students provided positive response 
Table 1. Students' perceived usefulness of Socrative.

\begin{tabular}{|c|c|c|c|c|}
\hline No & Items & $\mathrm{N}$ & A & SA \\
\hline 1 & $\begin{array}{l}\text { Using Socrative improves students' } \\
\text { mastery of English grammar }\end{array}$ & $\begin{array}{c}6 \\
(17.6 \%)\end{array}$ & $\begin{array}{c}21 \\
(61.8 \%)\end{array}$ & $\begin{array}{c}7 \\
(20.6 \%)\end{array}$ \\
\hline 2 & $\begin{array}{l}\text { Using Socrative gives student } \\
\text { greater control over the language learning }\end{array}$ & $\begin{array}{c}6 \\
(17.6 \%)\end{array}$ & $\begin{array}{c}15 \\
(44.1 \%)\end{array}$ & $\begin{array}{c}13 \\
(38.2 \%)\end{array}$ \\
\hline 3 & $\begin{array}{l}\text { Socrative enables students to } \\
\text { accomplish grammar tasks more quickly }\end{array}$ & $\begin{array}{c}5 \\
(14.7 \%)\end{array}$ & $\begin{array}{c}21 \\
(61.8 \%)\end{array}$ & $\begin{array}{c}8 \\
(23.5 \%)\end{array}$ \\
\hline 4 & $\begin{array}{l}\text { Socrative supports critical } \\
\text { aspects of students' study }\end{array}$ & $\begin{array}{c}7 \\
(20.6 \%)\end{array}$ & $\begin{array}{c}23 \\
(67.6 \%)\end{array}$ & $\begin{array}{c}4 \\
(11.8 \%)\end{array}$ \\
\hline 5 & $\begin{array}{l}\text { Using Socrative increases student became } \\
\text { an active student in the learning process }\end{array}$ & $\begin{array}{c}7 \\
(20.6 \%)\end{array}$ & $\begin{array}{c}19 \\
(55.9 \%)\end{array}$ & $\begin{array}{c}8 \\
(23.5 \%)\end{array}$ \\
\hline 6 & $\begin{array}{l}\text { Using Socrative improves students' } \\
\text { learning performance }\end{array}$ & $\begin{array}{c}3 \\
(8.8 \%)\end{array}$ & $\begin{array}{c}16 \\
(47.1 \%)\end{array}$ & $\begin{array}{c}15 \\
(44.1 \%)\end{array}$ \\
\hline 7 & $\begin{array}{l}\text { Using Socrative allows student to accomplish } \\
\text { more tasks than would otherwise be possible }\end{array}$ & $\begin{array}{c}6 \\
(17.6 \%)\end{array}$ & $\begin{array}{c}17 \\
(50.0 \%)\end{array}$ & $\begin{array}{c}11 \\
(32.4 \%)\end{array}$ \\
\hline 8 & $\begin{array}{l}\text { Using Socrative enhances students' } \\
\text { effectiveness on the learning }\end{array}$ & $\begin{array}{c}2 \\
(5.9 \%)\end{array}$ & $\begin{array}{c}19 \\
(55.9 \%)\end{array}$ & $\begin{array}{c}13 \\
(38.2 \%)\end{array}$ \\
\hline 9 & $\begin{array}{l}\text { Using Socrative makes it } \\
\text { easier to do grammar tasks }\end{array}$ & $\begin{array}{c}2 \\
(5.9 \%)\end{array}$ & $\begin{array}{c}16 \\
(47.1 \%)\end{array}$ & $\begin{array}{c}16 \\
(47.1 \%)\end{array}$ \\
\hline 10 & $\begin{array}{l}\text { Overall, I find Socrative } \\
\text { useful in learning grammar }\end{array}$ & $\begin{array}{c}1 \\
(2.9 \%)\end{array}$ & $\begin{array}{c}16 \\
(47.1 \%)\end{array}$ & $\begin{array}{c}17 \\
(50.0 \%)\end{array}$ \\
\hline
\end{tabular}

$\mathrm{N}=$ Neutral; $\mathrm{A}=$ Agree; $\mathrm{SA}=$ Strongly Agree .

with regard to "perceived usefulness of Socrative in learning grammar." In item $10,97 \%$ of students found that Socrative is a useful tool in learning grammar. The data also show that $94 \%$ of the students agreed that Socrative enhances their effectiveness on the learning of tenses, and it eased completion of grammar tasks. The use of Socrative to improve students' learning performance is also received well by the students at $91 \%$. The findings support Jamil and Shah's findings (2011), which stated that the integration of technology in the process of teaching and learning is vital in the attempt to enhance students' performance and the effectiveness of teaching tenses. The students also supported that Socrative enables them to complete grammar tasks more quickly, with $85 \%$ of them agreeing with the statement. Moreover, $82 \%$ of the students agreed with the idea that Socrative could improve their mastery of tenses, give them greater control over the language learning, and allow them to accomplish more tasks.

Besides that, $79 \%$ of students agreed with the fourth and fifth items, which stated that Socrative supports critical aspects of their study, and it encouraged them to become active participants in the learning process. This result supports Grave and Grabe's (2005) findings, which indicate that ICT could play various instructional roles. Among its roles are making students feel more relaxed in learning the various topics and completing tasks and also makes them active because they learn by integrating the technology to a task completion rather than 
by being directly "instructed" by the technology. It is also supported by Kaya and Balta (2016) who found that Socrative enhances the students' learning. While the students are answering the questions, they could see the results on the smart board, and when they finish answering the questions they see their mistakes. If they have any questions, they could ask their lecturer to explain the topic again, or they could eventually correct their mistakes. This measure informs both the students and the lecturer not to move to a new topic before covering the topic extensively.

Overall, the students' agreement about the usefulness of Socrative in tenses class shows positive responses, although sometimes they marked "neutral" as their response. However, none of the students gave negative responses toward Socratives' "perceived usefulness."

Table 2 shows the item numbers $2,4,6,8$, and 10 were positive, while item numbers $1,3,5,7$, and 9 were negative. For the positive statements, item 8 , which stated that the interaction with Socrative is easy, has the highest agreement (100\%), followed by item 4 , whereby $97 \%$ of the respondents agree toward the statement "Socrative eases my work." Then, Item 2 and Item 10 have similar responses: 94\% of the respondents stated "agree" that learning to use and to operate Socrative is easy for students. The students also feel that Socrative is an

'Table 2. Students' perceived Socratives' ease of use.

\begin{tabular}{|c|c|c|c|c|c|c|c|}
\hline No & Items & SD & $\mathrm{D}$ & $\mathrm{N}$ & A & SA & M \\
\hline 1 & $\begin{array}{l}\text { I find it cumbersome } \\
\text { to use Socrative }\end{array}$ & $\begin{array}{c}15 \\
(44.1 \%)\end{array}$ & $\begin{array}{c}14 \\
(41.2 \%)\end{array}$ & $\begin{array}{c}5 \\
(14.7 \%)\end{array}$ & - & - & 4.29 \\
\hline 2 & $\begin{array}{l}\text { Learning to operate } \\
\text { Socrative is easy }\end{array}$ & - & - & $\begin{array}{c}2 \\
(5.9 \%)\end{array}$ & $\begin{array}{c}9 \\
(26.5 \%)\end{array}$ & $\begin{array}{c}23 \\
(67.6 \%)\end{array}$ & 4.62 \\
\hline 3 & $\begin{array}{l}\text { Interacting with } \\
\text { Socrative is often frustrating }\end{array}$ & $\begin{array}{c}14 \\
(41.2 \%)\end{array}$ & $\begin{array}{c}17 \\
(50.0 \%)\end{array}$ & $\begin{array}{c}3 \\
(8.8 \%)\end{array}$ & - & - & 4.32 \\
\hline 4 & $\begin{array}{l}\text { I find that Socrative } \\
\text { eases my work }\end{array}$ & - & - & $\begin{array}{c}1 \\
(2.9 \%)\end{array}$ & $\begin{array}{c}18 \\
(52.9 \%)\end{array}$ & $\begin{array}{c}15 \\
(44.1)\end{array}$ & 4.41 \\
\hline 5 & $\begin{array}{l}\text { Socrative is rigid and } \\
\text { inflexible to interact with }\end{array}$ & $\begin{array}{c}17 \\
(50.0 \%)\end{array}$ & $\begin{array}{c}15 \\
(44.1 \%)\end{array}$ & $\begin{array}{c}2 \\
(5.9 \%)\end{array}$ & - & - & 4.44 \\
\hline 6 & $\begin{array}{l}\text { Socrative helps me to } \\
\text { remember to do tasks }\end{array}$ & - & - & $\begin{array}{c}3 \\
(8.8 \%)\end{array}$ & $\begin{array}{c}15 \\
(44.1)\end{array}$ & $\begin{array}{c}16 \\
(47.1)\end{array}$ & 4.38 \\
\hline 7 & $\begin{array}{l}\text { Interacting with Socrative } \\
\text { requires a lot of mental effort }\end{array}$ & $\begin{array}{c}15 \\
(44.1 \%)\end{array}$ & $\begin{array}{c}17 \\
(50.0 \%)\end{array}$ & $\begin{array}{c}2 \\
(5.9 \%)\end{array}$ & - & - & 4.38 \\
\hline 8 & $\begin{array}{l}\text { Interaction with } \\
\text { Socrative is easy }\end{array}$ & - & - & - & $\begin{array}{c}19 \\
(55.9 \%)\end{array}$ & $\begin{array}{c}15 \\
(44.1 \%)\end{array}$ & 4.44 \\
\hline 9 & $\begin{array}{l}\text { I find it takes a lot of } \\
\text { effort to become } \\
\text { skillful at using Socrative }\end{array}$ & $\begin{array}{c}20 \\
(58.8 \%)\end{array}$ & $\begin{array}{c}13 \\
(38.2 \%)\end{array}$ & $\begin{array}{c}1 \\
(2.9 \%)\end{array}$ & - & - & 4.56 \\
\hline 10 & $\begin{array}{l}\text { Overall, I find } \\
\text { Socrative is easy to use }\end{array}$ & - & - & $\begin{array}{c}2 \\
(5.9 \%)\end{array}$ & $\begin{array}{c}18 \\
(52.9 \%)\end{array}$ & $\begin{array}{c}14 \\
(41.2 \%)\end{array}$ & 4.35 \\
\hline
\end{tabular}

$\mathrm{SD}=$ Strongly Disagree; $\mathrm{D}=$ Disagree; $\mathrm{N}=$ Neutral; $\mathrm{A}=$ Agree; $\mathrm{SA}=$ Strongly Agree; $\mathrm{M}=$ Mean . 
easy way to remember how to do tasks at $91 \%$ of agreement (Item 6). For the negative statements, Item 9 has the highest percentage at $97 \%$. It shows students' disagreement toward the statement that it takes a lot of effort to become skilful in using Socrative. On the other hand, the students perceived that Socrative gives them flexibility in their task completion. It is shown by their disagreement toward the statement that Socrative is rigid and inflexible to interact with at $94 \%$, along with the statement that interacting with Socrative requires a lot of mental effort, which means that Socrative is easy to use for students because it does not need much effort to operate it. Then, $91 \%$ of students did not choose the statement that interaction with Socrative often makes them feel frustrated. This statement is followed by $85 \%$ of students who did not find it cumbersome to use Socrative. According to these findings, it could be concluded that all of the students have positive thoughts about Socratives' ease of use.

The findings indicate that students like Socrative because it explains every answer. This tool provides not only the answer to the questions, but the teacher could also give an explanation to the answers. Thus, the students would know their mistakes, and the program provides in-depth understanding on the tenses. The next responses indicate that the students like the types of questions provided by Socrative. There are multiple-choice, true-false, and short answers. Thus, the students are not bored of similar types of questions. Other responses show that they like Socrative because this tool is easy to use, and the instructions are clear.

The vast majority of respondents mentioned that they dislike the use of Socrative because it requires an Internet connection, and some universities have unstable Internet connections. Some students also did not have a sufficient Internet quota, so they had to ask for their friends' personal hotspot. One student stated that he/she does not like Socrative because the students' answers were projected on the screen, which could be viewed by their classmates. This happened because Socrative provides a real-time response to the students' responses. So, the lecturers would know their level of understanding immediately. When the lecturer used the projector to show their performance, the students who made mistakes would feel embarrassed. It is in line with Kaya and Balta (2016) who found that, in the learning process, while the students are answering the questions, they could see the results on the smart board when they finished answering the questions. This is good because if the students make a mistake, they could ask their lecturer to explain the topic again or correct their mistakes.

The students were also asked to answer a question on their interest in using Socrative in the future. The results indicate that 27 students or $79.4 \%$ of them responded favourably to the idea of using Socrative to enhance their English competency. Only seven students or $20.6 \%$ of the population responded "maybe" or "neutral" on using this tool in the future.

\subsection{Lecturers' Perceptions toward Socrative}

In this section, the researchers only provide the frequency of the lecturers' per- 
ceptions because only two lecturers were involved in the study. The findings in Table 3 show the lecturers' perceived usefulness of Socrative in learning grammar particularly tenses was positive.

Although both lecturers chose the neutral perception that Socrative could improve students' learning performance, only one lecturer disagreed with the statement that Socrative could promote students' active involvement in the learning process. She felt that students would focus too much on their smartphones or gadgets and not pay attention to the learning activity. Since the number of the students is large, the lecturers could not monitor their students' work. They claimed in the open-ended questions that a few students took the opportunity to check their Whatsapp, Facebook or Instagram messages before completing their Socrative quiz thus wasting the class time ("We could not monitor each student. They read other messages from the social media like Whatsapp, FB or Instagram. This is wasting our time"). The lecturer's claim is against Awedh, Mueed, Zafar, and Manzoor's (2014) positive findings on the effects of Socrative. The results indicated that collaborative learning and students' participation improved students' learning performance. The results contradicted Grave and Grabe's findings (2005), which showed that ICT make students more relaxed to learn, and they become more participative.

However, both lecturers agreed with almost all items. They found that Socrative could improve students' mastery of English grammar and the ability to complete grammar tasks easier and faster. Socrative allows students to accomplish more tasks. They also agreed that using Socrative could enhance students' learning effectiveness. They agreed that Socrative gives students greater control over the language learning because it supports students' critical thinking. In conclusion, both lecturers found that Socrative is useful in learning tenses.

For perceived ease of use, the questionnaire consists of five positive and five negative statements. Item numbers $2,4,6,8$, and 10 were positive, while item

Table 3. Lecturers' perceived usefulness of Socrative.

\begin{tabular}{cccccc}
\hline No & Items & D & N & A & SA \\
\hline 1 & Using Socrative improves students' mastery of English grammar & - & - & 1 & 1 \\
2 & Socrative gives students greater control over the language learning & - & - & - & 2 \\
3 & Socrative enables students to complete grammar tasks more quickly & - & - & - & 2 \\
4 & Socrative supports students' critical thinking & - & - & 1 & 1 \\
5 & Socrative promotes students' active involvement in the learning process & 1 & 1 & - & - \\
6 & Socrative improves students' learning performance & - & 2 & - & - \\
7 & Socrative allows students to accomplish more tasks & - & - & - & 2 \\
8 & Socrative enhances students' effectiveness on the learning & - & - & 2 & - \\
9 & Socrative makes it easier to do grammar tasks & - & - & - & 2 \\
10 & Overall, I find Socrative is useful in learning grammar & - & - & 2 & - \\
\hline
\end{tabular}

$\mathrm{D}=$ Disagree $\mathrm{N}=$ Neutral A = Agree SA = Strongly Agree. 
numbers $1,3,5,7$, and 9 were negative. For the positive statements, both lecturers gave the highest agreement toward Socratives ease of use. It could be seen (refer to Table 4) that none of them chose "disagree" nor "strongly disagree" toward a positive statement. However, only one of them chose "neutral" in regards to the statement "Socrative is easy to be operated." According to one of the lecturers in the open-ended question, everything is acceptable except for at times he/she faced a problem with the Internet connection ("There are times which the internet was disconnected or the wavelength was very low that make the students took a long time to answer Socrative questions"). Thus, the Socrative could not be conducted smoothly and effectively if the institution has poor internet connection.

As for the negative statements, Table 4 shows that none of the lecturers concurred with the negative statements. It could be concluded that they perceived well toward Socrative's ease of use even though with a few limitations namely poor internet connection and students' tendency to read other messages from the social media. The advantages outweigh the disadvantages. Both of them rejected that Socrative is cumbersome, rigid, and inflexible to use in grammar class. They also rejected the idea that it takes a lot of effort to become skilful at using Socrative. Overall, the lecturers found that Socrative is easy to use in the teaching and learning process of tenses.

Other lecturers' perceptions toward Socrative also show many interesting responses. Based on their responses on preference, a lecturer stated that he/she likes Socrative because it is an easy and good way to know students' prompt understanding of the material. By giving them quizzes through Socrative, the lecturer would be able to know students' understanding, so that he/she could re-explain the parts which the students could not fully grasp or understand. But, based on what he/she dislikes, the lecturer stated that Socrative could only be

Table 4. Lecturers' perception on Socratives' ease of use.

\begin{tabular}{|c|c|c|c|c|c|}
\hline No & Items & $\mathrm{D}$ & $\mathrm{N}$ & A & SA \\
\hline 1 & It is cumbersome to use Socrative & - & 2 & - & - \\
\hline 2 & Learning to operate Socrative is easy & - & - & - & 2 \\
\hline 3 & Interaction with Socrative is often frustrating & 1 & 1 & - & - \\
\hline 4 & Socrative is easy to be operated & - & - & 1 & 1 \\
\hline 5 & Socrative is rigid and inflexible to interact with & 1 & 1 & - & - \\
\hline 6 & Socrative is easy for me to remember how to do tasks & - & - & - & 2 \\
\hline 7 & Interaction with Socrative requires a lot of mental effort & 2 & - & - & - \\
\hline 8 & Interaction with Socrative is easy for me & - & - & - & 2 \\
\hline 9 & It takes a lot of effort to become skilful in using Socrative & 1 & 1 & - & - \\
\hline 10 & Overall, I find Socrative is easy to use & - & - & - & 2 \\
\hline
\end{tabular}

$\mathrm{D}=$ Disagree $\mathrm{N}=$ Neutral A = Agree SA = Strongly Agree. 
used when there is an Internet connection. However, in this faculty, the Wi-Fi connection is unstable, and students have to register prior to using it. Moreover, many of them still did not pay attention to the classroom activities; thus, when using Socrative, the students used their own Internet quota. Sometimes they complained because their quota is running out.

The other lecturer stated that Socrative saved his/her time in giving tasks or quizzes to the students. He also mentioned that this tool could enhance students' motivation in learning because of the variation in learning. Usually, the lecturer only uses the PowerPoint slide to give variations in teaching. According to Chien, Yunus and Mohamad (2008) the integration of ICTs boosts learners' motivation because of multimedia capabilities, including visual aids, audios, and videos." Then, based on what he/she dislikes, the lecturer further clarified that there is no specific answer toward this question because he/she really likes using this tool. The findings also highlight that both lecturers agreed to use this tool in the future, especially for the teaching of grammar.

\section{Conclusions}

The researchers were able to shed light on two research questions of this study: 1) What are the Indonesian undergraduates' perceptions toward Socrative? 2) What are the lecturers' perceptions toward the use of Socrative in teaching grammar? The findings clearly indicated that students and lecturers have positive perceptions toward Socrative. The findings show that they have positive thoughts on the Socratives' usefulness and ease of use in grammar class. It means that they accept this tool in language learning. The findings also support the technology acceptance model (Davis, 1989). The conclusion is derived from their willingness to use Socrative in the future. Thus, students and lecturers agreed to use this tool in the future.

This study offers some implications. Socrative not only could be used in the teaching of tenses but also in all aspects of grammar. Socrative could assist Indonesian educators to teach more creatively. Socrative can be used to gauge students' understanding toward lessons. This study also has limitations. It was a small-scale study. Only one class of 34 students and two lecturers from English study program at Islamic University of Riau (UIR) were involved. This is because there were the only two lecturers who taught grammar classes for the sixth semester. It is suggested that a bigger sample should be used for future study in order for the results to be generalized to a bigger population. Since this is a case study, the results could not be generalized to the bigger population. It could only applicable if the students or population has similar characteristics with the characteristics of the participants in this study.

\section{Conflicts of Interest}

The authors declare no conflicts of interest regarding the publication of this paper. 


\section{References}

Al-Munawwarah, S. F. (2014). Teachers' Perceptions on the Use of ICT in Indonesian EFL Learning Context. English Review. Journal of English Education, 3, 70-80.

Awedh, M., Mueen, A., Zafar, B., \& Manzoor, U. (2014). Using Socrative and Smartphones for the Support of Collaborative Learning. International Journal on Integrating Technology in Education (IIITE), 3, 17-24. https://doi.org/10.5121/ijite.2014.3402

Barnawi, O. Z. (2009). The Internet and EFL College Instruction: A Small-Scale Study of EFL College Teachers' Reactions. International Journal of Instructional Technology \& Distance Learning. http://www.itdl.org/Journal/Jun_09/article04.htm

Bolandifar, S. (2013). The Teachers' Attitudes toward Integrating Internet Technology in English Language Classes. International Journal of Language and Applied Linguistic World, 4, 81-93.

Chien, C. H., Yunus, M. M., \& Mohamad, M. (2008). "Who We Are" in Enhancing Rural Students' English as a Second Language (ESL) Learning. American Journal of Educational Research, 1, 162-167.

Dashtestani, R. (2012). Barriers to the Implementation of Call in EFL Courses: Iranian EFL Teachers' Attitudes and Perspectives. JALT Call Journal, 8, 55-70.

Davis, F. D. (1989). Perceived Usefulness, Perceived Ease of Use, and User Acceptance of Information Technology. MIS Quarterly, 13, 319-340. https://doi.org/10.2307/249008

Dervan, P. (2014). Enhancing In-Class Student Engagement Using Socrative (an Online Student Response System): A Report. AISHE-J, 6, 1977-1983.

Grave and Grabe (2005). Integrating Technology for Meaningful Learning. USA: Houghton Mifflin.

Jamil, M., \& Shah, J. H. (2011). Technology: Its Potential Effects on Teaching in Higher Education. New Horizons in Education, 59, 38-51.

Kaya, A., \& Balta, N. (2016). Taking Advantages of Technologies: Using the Socrative in English Language Teaching Classes. International Journal of Social Sciences \& Educational Studies, 2, 4-12.

Mappiasse, S. S., \& Sihes, A. J. (2014). Evaluation of English as a Foreign Language and Its Curriculum in Indonesia: A Review. English Language Teaching, 7, 113-122. https://doi.org/10.5539/elt.v7n10p113

O'Keeffe, M. (2012). Enhancement of Learning with Classroom Response Systems (Clickers)_Lecturer Reports and Feedback. Dublin Institute of Technology. http://www.dit.ie/lttc/media/ditlttc/clickers/Clicker_report_July_2011.pdf

Sudiran (2015). Students' Perception towards the Use of Internet as Learning Media to Promote Reading Comprehension Skill. Sino-US English Teaching, 12, 684-692.

Yuhetty, H. (2002). ICT and Education in Indonesia. http://unpan1.un.org/intradoc/groups/public/documents/apcity/unpan011286.pdf 